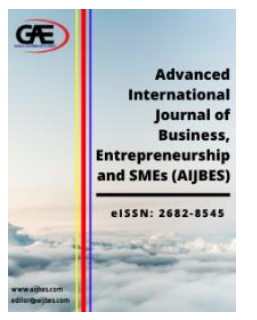

\author{
ADVANCED INTERNATIONAL JOURNAL OF \\ BUSINESS, ENTREPRENEURSHIP AND SMES \\ (AIJBES) \\ www.aijbes.com
}

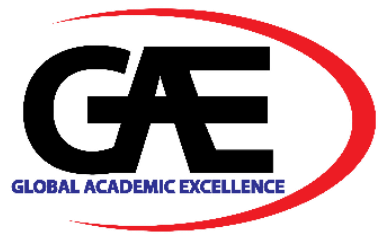

\title{
CHINESE ENTREPRENEURIAL CAPABILITIES AND PRACTICES: CASE OF MALAYSIAN SME
}

\author{
Yeng Wai Lau ${ }^{1 *}$, Wei Keng Cheah $^{2}$, Asna Atqa Abdullah ${ }^{3}$ \\ 1 School of Business and Economics, Universiti Putra Malaysia, Malaysia \\ Email: wai_ly@upm.edu.my \\ 2 Putra Business School, Universiti Putra Malaysia, Malaysia \\ 3 School of Business and Economics, Universiti Putra Malaysia, Malaysia \\ Email: asnaatqa@uum.edu.my \\ * Corresponding Author
}

\section{Article Info:}

\section{Article history:}

Received date: 17.08 .2020

Revised date: 12.09 .2020

Accepted date: 14.09 .2020

Published date: 15.09 .2020

\section{To cite this document:}

Lau, Y. W., Cheah, W. K., \& Abdullah, A. A. (2020). Chinese Entrepreneurial Capabilities and Practices: Case of Malaysia SME. Advanced International Journal of Business, Entrepreneurship and SMEs, 2 (5), 15-29.

DOI: $10.35631 /$ AIJBES.25002.

\begin{abstract}
:
Extant literature suggests that the influence of entrepreneurial capabilities and practices on business performance is inconclusive especially with the use of questionnaire surveys where the complexity of the contexts of study is overlooked. This study examines how Chinese SMEs' entrepreneurial capabilities and practices are continuously developed in response to changing contextual circumstances in Malaysia. This study appraises the inextricable connection between the historical development of Malaysia and Chinese entrepreneurial capabilities and practices. An interpretive case study was conducted where interviews with the founder cum owner-manager, project managers, administrative and operational personnel shed light on how the case firm overcomes various challenges and captures opportunities in the process of developing entrepreneurial capabilities and practices for more than four decades. Chinese SMEs demonstrate a staunch desire for self-sufficiency and progress in the face of adversity. The case firm demonstrates constant upgrade in efficiency, effectiveness, and contributions to the value chain, which reflects the very essence of entrepreneurship, i.e. from rags to riches. The results of this study serve as a guide for aspiring entrepreneurs. As for policymakers, this study sheds light on the importance of initiatives aimed at character-building to promote life-long learning among SMEs rather than financial assistance, which does little to encourage the quest for self-sufficiency.
\end{abstract}

Keywords:

Entrepreneurial Capabilities, Entrepreneurial Practices, SME, Chinese, Malaysia 


\section{Introduction}

Business success is widely believed to be attributable to the entrepreneur and his/her capabilities. For example, fast food restaurant chain Kentucky Fried Chicken's success is attributable to its founder, Colonel Sanders. Internet-based business Alibaba Group's success is also attributable to its founder, Jack Ma. However, empirical evidence on the extent to which the entrepreneur and his/her capabilities contribute towards business success is inconclusive. On one hand, entrepreneurial capabilities have been found to facilitate change in strategies to capture opportunities and improve firm performance (Ahmad et al., 2010; Li et al., 2011). On the other hand, deemed less capable entrepreneurs with a working and peasant class background have been found to outperform their more capable counterparts from the white collar, knowledge industry and professional class in identifying opportunities ( $\mathrm{Li} \&$ Gustafsson, 2012).

Much is to be learned about the complexity of entrepreneurial capabilities as the contexts of study are often simplified and underappreciated in extant literature especially to ensure ease of operationalization of questionnaire surveys (e.g. Ahmad et al., 2010; Li et al., 2011; Rahman et al., 2015; Sarwoko et al., 2013; Li \& Gustafsson, 2012; Song et al., 2015). The contexts in manifold facets provide opportunities as well as set boundaries for entrepreneurial potentials (Welter, 2011). Southeast Asia, especially Malaysia, constitutes a fascinating context as Chinese entrepreneurs thrive even with little economic opportunities and numerous constraints. Despite being at a disadvantage ever since the day their forefathers migrated from China, Chinese entrepreneurs rise to become dominant economic players in Southeast Asia (e.g. Ghosh \& Abdad, 1998; Ho, 2006; Wee et al., 2006; Khong \& Jomo, 2010; Chin, 2012; Chin $\&$ Teh, 2017).

This study examines the recursive link between the Malaysian historical context and Chinese small and medium-sized enterprises' (SMEs) entrepreneurial capabilities and practices. More specifically, this study examines how historical development in Malaysia shapes Chinese SMEs' entrepreneurial capabilities and practices, which in turn contribute towards the country's historical development. SMEs play an important role in growing a strong middle class and China boasts of the largest middle class in the world (Yan, 2015). Overseas Chinese entrepreneurs are deemed the cream of the crop whose business practices, though not representative, are comparable with those of contemporary mainland Chinese entrepreneurs (Schlevogt, 2002; p. 48). This study sheds light on how best to promote development of SMEs for a strong middle class.

This study contributes to extant literature in three major ways. First, there is a paucity of microlevel research on Chinese entrepreneurial practices especially when Chinese entrepreneurs are inclined to keep a low profile and do not readily reveal their business and entrepreneurial practices (Ahlstrom et al., 2004; Schlevogt, 2002). Second, using primarily questionnaire surveys, extant literature provides inconclusive findings on how entrepreneurial capabilities and practices contribute towards business performance and success (e.g. Ahmad et al., 2010; Li et al., 2011; Li \& Gustafsson, 2012). Third, what is business success and what contributes towards business success have been contended as not readily determinable based on conventional theories and research methods (e.g. Belassi \& Tukel, 1996; Constantino et al., 2015). This study offers insights into Chinese entrepreneurial practices and success using an alternative, case approach. 
Findings of this study can serve as a learning platform for entrepreneurs as well as policy makers. Various government initiatives aimed at helping SMEs have been found to be ineffective primarily because SMEs are unaware how to help themselves in the first place, let alone benefit from government assistance (e.g. Saleh \& Ndubisi, 2006). Despite little evidence of success, various government initiatives are continuously introduced worldwide to enable SMEs to overcome constraints of economic resources and expertise particularly when SMEs' contributions towards GDP growth and creation of employment opportunities are equally important to both high-income and low-income nations (e.g. Elinio, 2009; Saleh \& Ndubisi, 2006; Wonglimpiyarat, 2011). A better understanding of Chinese SMEs' entrepreneurial capabilities and practices helps aspiring entrepreneurs to improvise their business practices. Further, government initiatives can be better aligned to promote best business practices and success among SMEs.

The remainder of this paper is organized as follows. The second section provides a review of literature. The third section details the historical development of Chinese entrepreneurs in Malaysia. The fourth section discusses the case method and findings. The final section concludes the discussion.

\section{Literature Review}

Quest for a comprehensive set of entrepreneurial capabilities that managers and/or key personnel managing SMEs should possess is fraught with difficulties as much is still to be learned about the complex set of entrepreneurial capabilities ranging from personality traits, values, motives and family background to technical knowledge, relationship-building skills and innovativeness (Ahmad et al., 2010; Bird, 1995; Mitchelmore \& Rowley, 2010; Li et al., 2011; Rahman et al., 2015; Song et al., 2015). Indeed, entrepreneurship is complex (see Timmons, 1989). In line with the complexity of entrepreneurship, various terminologies have been used interchangeably in extant literature to refer to entrepreneurial capabilities, such as skills, expertise, acumen, competency, entrepreneurial orientations and entrepreneurial contexts (Michelmore \& Rowley, 2010; Li et al., 2011; Song et al., 2015). Further, prior studies fail to measure entrepreneurial capabilities in a manner that comprehensively captures its complexity with a questionnaire instrument resulting in inconclusive findings not to mention self-response biases (e.g. Ahmad et al., 2010; Li et al., 2011; Rahman et al., 2015; Sarwoko et al., 2013; Li \& Gustafsson, 2012; Song et al., 2015).

In addition to being complex, the set of entrepreneurial capabilities is subject to evolution and even revolution in response to changing circumstances (Bird, 1995). Extant literature suggests that entrepreneurs require a different set of capabilities to cope in a different economic environment, to manage business of different sizes and in different life-cycle stages as well as to perform different tasks (Ahmad et al., 2010; Bird, 1995; Mitchelmore \& Rowley, 2010). In other words, the influence of entrepreneurial capabilities cannot be readily disentangled from the contexts of study. Extant literature primarily focuses on the effects of entrepreneurial capabilities on the outcome, such as firm performance and success (e.g. Ahmad et al., 2010; Rahman et al., 2015; Sarwoko et al., 2013; Song et al., 2015). Much is still to be learned about the process of when, how and why entrepreneurship succeeds (Welter, 2011). How entrepreneurial capabilities evolve while being applied in response to changing contextual conditions are equivocal. 
In a Malaysian setting, this study examines how entrepreneurial capabilities enable coping with various contextual conditions, while these entrepreneurial capabilities are honed and developed in the process. Extant literature suggests that there are two major components of entrepreneurial capabilities, i.e. the "nature" and "nurture" component (e.g. Ahmad et al., 2010; Bird, 1995; Mitchelmore \& Rowley, 2010; Li \& Gustafsson, 2012). The "nature" component is innate, deeply ingrained and difficult to change such as personality, attitude and culture. The "nurture" component can be readily acquired through training as well as practice such as knowledge and skills. It is believed that even the "nature" component can be developed, though a longer period of time is required, with consistent practice in thinking and acting like an entrepreneur (Neck \& Greene, 2011).

Examining the interplay between entrepreneurial capabilities and contextual circumstances provides a better understanding on how entrepreneurs think and act, which this study aims at achieving in the case of Chinese SMEs in Malaysia. Extant literature suggests that entrepreneurial capabilities primarily facilitate business performance and success in a hostile and challenging environment (Ahmad et al., 2010). Similarly, history suggests that Chinese entrepreneurs in Southeast Asia rose to become dominant economic players in the face of hostility and discrimination (e.g. Ghosh \& Abdul, 1998; Ho, 2006; Wee et al., 2006; Khong \& Jomo, 2010; Chin, 2012; Chin \& Teh, 2017). Beyond Southeast Asia, Chinese entrepreneurs are also known for their propensity to conquer impossible markets (e.g. Cook et al., 2016). Little is known how Chinese entrepreneurs think and act in response to various obstacles to thrive against all odds.

\section{Chinese Entrepreneurs in Malaysia: A Brief History}

\section{Development of Entrepreneurial Capabilities}

European colonization brought about migration of the Chinese primarily from the south-eastern parts of China to Southeast Asia for economic purposes. In the 19th centuries, the British government encouraged mass migration of the Chinese to the then Federated Malay States (i.e. Malaysia today) to supply labour to the mining and trading sector; the Chinese constituted $66.0 \%$ and $65.3 \%$ of the labour force in the mining and commerce industry, respectively (Rao et al., 1977: p. 19). Chinese immigrants' propensity to take risks was reflected in their courage to brave stormy seas and cross borders into unchartered territory. Indeed, overseas Chinese, i.e. Chinese immigrants and their descendants in Malaysia, are not only known for being risktaking, but also hardworking, thrifty and self-reliant as they ploughed through the many constraints imposed on them ranging from economic and labour market discrimination to uneven distribution of public resources in education (Ghosh \& Abdad, 1998; Wee et al., 2006). Such qualities equipped overseas Chinese to start from scratch in an unchartered territory and rose to dominate the middle class and some even gained the colonial government's trust and appointed to positions of power (Ghosh \& Abdad, 1998).

Overseas Chinese have long embraced the goal of wealth maximization, which is the primary goal of a typical for-profit business. Indeed, overseas Chinese has been claimed to embrace wealth maximization in every aspect of life like a religion (Ghosh \& Abdad, 1998). When the materialistic culture was superimposed on the nation under the British colonial regime, overseas Chinese experienced little difficulties adapting and reaped the most economic benefits compared with the indigenous locals and other ethnic groups (e.g. Ghosh \& Abdad, 1998). When the indigenous locals and other ethnic groups eventually embraced the materialistic 
culture, the goal of wealth maximization became the Malaysian nation's institutionalized principle, which drove the nation's post-independence development initiatives (see Lau, 2013).

Having to survive in a foreign land also honed overseas Chinese's adaptability skills. Seen as non-indigenous, overseas Chinese were compelled to adapt to demonstrate political loyalty towards their country of residence (Wee et al., 2006). In Malaysia and neighbouring Southeast Asian countries, overseas Chinese assimilated via marriage with the indigenous locals, conversion to Islam and trading with the non-Chinese business communities. Even the Chinese in Singapore where the Chinese constitutes a majority of the population were not spared from having to adapt as Singaporean "Chineseness" is different from the "Chineseness" of mainland Communist China then (Wee et al., 2006: p. 371).

Overseas Chinese's propensity to take risks and adaptability are comparable to the characteristics of contemporary Chinese entrepreneurs; contemporary Chinese enterprises are known for their adaptability to changing circumstances and their bold, novel and risky strategies to increase market share (Schlevogt, 2002). How overseas Chinese entrepreneurial capabilities are aligned with their business practices are discussed in the following subsection.

\section{Business Practices}

Extant literature suggests that overseas Chinese businesses are typically family owned and operated (Ahlstrom et al., 2004; Wee et al., 2006). Family members and trusted, close friends typically occupy key strategic positions in the business to safeguard controlling interests from outsiders. In line with the importance of maintaining controlling interests within family members, the organizational structure of overseas Chinese businesses also tends to be simple to enable the few family members and trusted close friends in key strategic positions to oversee and direct most business activities. Governance and decision-making authorities are also in the hands of the few family members and trusted close friends. Such a simple organizational structure where a few hands-on managers monitor the business operations is more adaptive and in a better position to respond to changing circumstances in a timely manner in comparison with a complex organizational structure with a hierarchy of authority and established set of policies and rules (Reeves \& Deimler, 2011).

The few key managers who oversee, direct and make most of the decisions related to the business tend to be the only few people who know the business well. Information tend to remain with the few key managers; it is a typical characteristic of overseas Chinese business to keep a low profile and operate in a simple value chain that is easy to maintain and control without having to share much information with employees and trading partners (Ahlstrom et al., 2004). Such information is only pass on to family members and trusted close friends who subsequently inherit or takeover the business.

Consistent with a simple organizational structure with little policies and rules to follow, most of the major business decisions are made in an informal manner based on the experience and intuition of the few hands-on owner-managers (Huang, 2009). Making decisions in this manner can work both ways. On one hand, making decisions in this manner is believed to be based on a highly developed form of reasoning that enables one to be lucky as one is in a position to recognize chance opportunities that cannot be found via systematic search and analysis of information (Matzler et al., 2007). Being able to recognize and respond fast to chance 
opportunities enhance adaptability but can be risky as decisions are often made in haste with little support of facts, evidences and justifications (Huang, 2009).

\section{Economic Environment}

In Malaysia, Chinese entrepreneurs' propensity to take risks and adaptability with the goal of wealth maximization paid off as reflected in the country's wealth distribution that favoured the Chinese since the colonial days. Socio-economic inequalities inherited from the colonial times continued post-independence as parental socio-economic status determined educational and economic attainment, which led to indigenous resentment (Ghosh \& Abdad, 1998; Khong \& Jomo, 2010; Chin, 2012; Chin \& Teh, 2017). Similarly, in neighbouring Southeast Asian countries like Indonesia, Chinese entrepreneurs constituting 3\% of the nation's population were also stigmarised and marginalized as being economically strong (Wee et al., 2006).

Indigenous resentment and the resultant racial disharmony led to various economic reform initiatives such as the New Economic Policy in the 1970s, National Development Policy in the 1990s, National Vision Policy in the 2000s and New Economic Model introduced in 2009 (e.g. Ghosh \& Abdad, 1998; Wee et al, 2006; Khong \& Jomo, 2010; Chin, 2012; Chin \& Teh, 2017). Such economic reform initiatives aimed at eliminating identification of economic function with ethnicity for fairer distribution of wealth. Under such initiatives, distribution of public resources was skewed towards enhancing access to education and economic opportunities for the indigenous community. Foreign capitalists were also invited to accelerate the country's economic development, but the growth rate of Chinese capital overtook the growth rate of these foreign capital; Chinese SMEs thrived despite intense competition and various constraints (Ghosh \& Abdad, 1998; Ho, 2006).

Prior to such economic reforms, overseas Chinese faced an even more adverse environment. More specifically, overseas Chinese first migrated to escape famine and war in Southern China for greener pastures, i.e. to offer cheap labour primarily to the mining industry during the colonial days. At a time when minimization of the wage bill was pertinent for profit maximization, there was no official policies to protect the rights of these Chinese resulting in labour exploitation and high mortality rate attributable to malnutrition and overwork (see Khong \& Jomo, 2010).

Such adverse environment served as a platform for the Chinese to hone pertinent entrepreneurial capabilities like risk taking, resilience, diligence and adaptability. The goal of wealth maximization was the overriding objective that drove migration of the Chinese in the first place (Ghosh \& Abdad, 1998). Obstacles like language and cultural barriers and even oppressions like severe labour exploitations were relegated to the background. The Chinese were willing to sacrifice many things to rise above various obstacles and oppressions; Chinese workers were known for being more skilful, hardworking and productive, and thus garnered better pay than other ethnic groups (Khong \& Jomo, 2010). Having gathered sufficient skills and capital resources, these Chinese resorted to self-employment.

\section{Coping with Adversity}

Despite unfavourable economic reforms, Chinese businesses thrived with the support of a close-knit network of family members and trusted close friends (Ghosh \& Abdad, 1998; Wee et al., 2006). Having ownership and control of their businesses in the hands of a few family members and trusted close friends minimize agency problems. Further, while family altruism 
fosters commitment, loyalty, trust and effective use of knowledge and skills, trusted close friends typically have close social ties with the family and are chosen for the relevance of their knowledge and skills, which they are obliged to demonstrate especially in the face of adversity (Zattoni et al., 2015).

Chinese entrepreneurs are also known for being capable of transforming political capital into economic capital by associating with powerful indigenous entrepreneurs and allocating shares to their indigenous business partners capable of securing lucrative business projects (Ho, 2006; Wee et al., 2006). The Malaysian government is supportive of such inter-racial business partnerships to build a friendly system of partnership capitalism in Malaysia, especially when decades of economic policies that favour the indigenous locals at the expense of other ethnic groups have caused continuous exodus of capital and outward migration of talent (Chin, 2012; Chin \& Teh, 2017). Business partnerships between Chinese entrepreneurs and their indigenous allies frequently begin with the goal of wealth maximization. As business partners learn, adjust and develop trust over time, such business partnerships become genuine as business partners become more conscious of the importance of knowledge sharing and their roles as contributors as well as beneficiaries of the resultant economic integration and national unity of the country (Ho, 2006; Chin, 2012).

Chinese entrepreneurs are also known for their strong business networks that contain pertinent value chain participants, i.e. suppliers, manufacturers, distributors, retailers and customers; such strong business networks or value chains are crucial to Malaysia's position as a leader in the manufacturing sector, especially electrical and electronics manufacturing, in Southeast and East Asia, which attracts foreign direct investment (Chin, 2012). Believed to be the most advanced in the world, such business networks or value chains in Southeast and East Asia are connected to the global value chain system that serves the global marketplace (Harvie, 2015). To survive increasing competition and economic liberalization in the global marketplace, it is crucial for Chinese SMEs, especially subcontractors and suppliers of parts, intermediate products and industrial equipment to multinational corporations and large domestic entreprises, to be a part of such business networks or value chains to have the advantage of economies of scale and branding for survival and sustainable growth in the long-run (Chin, 2012; Harvie, 2015; Chin \& Teh, 2017). In order to move up the hierarchy to become preferred, first-tier subcontractors and suppliers in the global value chain system, SMEs must demonstrate efficiency, effectiveness and constant upgrade in their contributions to the value chain. Otherwise, SMEs risk remaining at the low, entry-level tier where they are readily replaceable (Harvie, 2015).

When economic liberalization and deregulation are believed to be the only way forward with the onset of globalization, few indigenous entrepreneurs are feared to be ready despite four decades of economic policies that favour the indigenous community. More specifically, economic policies that aimed at fairer distribution of wealth across ethnic groups have inadvertently promoted rent-seeking and created opportunities for wealth accumulation among the elite resulting in an intra-ethnic wealth gap within the indigenous community; few indigenous entrepreneurs are equipped with the pertinent entrepreneurial capabilities to start and run their own businesses (see Chin, 2012; Chin \& Teh, 2017). The next section details how the founder cum owner-manager of the case firm cultivated and made use of his entrepreneurial capabilities to start and run his own business. 


\section{Case Study}

\section{Research Method}

Interpretive case study is suitable for an in-depth understanding of how changing contextual circumstances shape entrepreneurial capabilities as well as entrepreneurs' responses, which in turn, influence contextual circumstances (see Dyer \& Wilkins, 1991; Myers, 2009). As this study involves understanding the dynamics of the entrepreneurs' interaction with contextual circumstances, the unit of analysis is a combination of the case firm, the firm's owners and/or managers, and impactful events - opportunities and challenges - with the emphasis on the case firm, owners and/or managers' decisions and actions in response to impactful events. Access to owners and/or managers who are in a position to provide a rich and concrete account of the firm's historical development, especially in terms of impactful, life-changing events, key decisions made, and actions taken at each pertinent junction of the development of the case firm is important. A high degree of trust, commitment as well as willingness to open up and disclose detailed account of critical events, decisions and actions that contribute towards the survival and success of the case firm over the years are pertinent for an in-depth insights into the dynamics and intricacies underlying the case firm and its environment. Personal networks of the researchers were used to solicit participation of the case firm. Use of personal networks also enabled the researchers to glean information from the participating case firm on a regular basis formally as well as informally.

Primarily semi-structured interviews were conducted to understand the contexts, events and developments that impacted the case firm, decisions made and/or actions taken in response, and how decisions and actions influenced subsequent events and developments. Secondary data - minutes of meetings, organization charts, financial and management reports-were also collected to corroborate interview findings. Each interview was conducted face-to-face to establish rapport, build trust and identify non-verbal cues for further investigation. Interviews were conducted in a combination of Malay, Chinese and English language depending on the preference and background of each interviewee. The first five to 10 minutes of each interview were typically spent on building rapport where both researcher and interviewee got to know each other. While building rapport and ensuring interviewee was at ease, the purpose of the research, assurance of confidentiality and anonymity as well as interviewee's option to withdraw were also explained. While all interviewees were asked about the same themes, formulation of questions were adapted, and terminologies were chosen in a manner suitable to each interviewee's background and educational level. Notes were taken throughout each interview. Immediately after each interview, notes were reviewed, and additional notes were included to improve clarity of the interview transcript. When interview findings became repetitive with no new issues surrounding contexts, events, developments of the case firm as well as decisions and actions taken, two more interviews were conducted to ensure that no new issues emerged; saturation was achieved (e.g. Saunders et al., 2017).

Case findings are organized in themes as well as in chronology. The case findings contain historical development of the case firm, especially in terms of major events - opportunities and threats - and their impact on the life of the owners, managers and case firm, and decisions and actions taken as a consequence, which gave rise to subsequent impactful events with the corresponding decisions as well as actions on the part of the owners, managers and case firm; the case findings contain series of intertwined events, decisions and actions. The case findings 
were shared with the interviewees to avoid misunderstanding and inaccurate historical facts. The remainder of this section details the case findings.

\section{Entrepreneurial Capabilities of the Founder and the Business}

In 1968, CC, founder of the case firm, left his hometown in Ipoh for his first job as a mechanic in Kuala Lumpur, the capital city of Malaysia. CC was 16 years old and eager to contribute to the economic well-being of his family. Quest for better-paying jobs-goal of wealth maximization - motivated CC to leave his hometown for the capital city. As a heavy machinery mechanic, $\mathrm{CC}$ was responsible for servicing, repairing and maintaining machinery and equipment used primarily in the construction industry. CC's salary as a mechanic in Kuala Lumpur was thrice that of an average farmer or miner in his hometown. Despite getting a better salary, CC felt a lack of progress and personal development as a mechanic. CC subsequently accepted a job offer as an excavator operator where he learned how to operate heavy machinery and equipment at construction sites. Equipped with the knowledge and expertise in operating as well as repairing and maintaining heavy machinery and equipment, $\mathrm{CC}$ felt the need to start his own business in providing earthwork services. CC borrowed from his relatives to purchase his first excavator and business operations began.

As a sole proprietorship, the business was in a capacity to provide earthwork services only, which CC felt was insufficient. CC was determined to expand his business into providing rock hacking and demolition services with the use of hydraulic breaker to increase revenue. In line with business expansion, CC invited his nephew, MW, and his older brother, CT, to form a partnership in the early 1980s. The new business, i.e. partnership, was named after a hydraulic breaker manufacturer to help promote the manufacturer's products in return for a discount for all machinery and equipment purchased. The partnership prospered as indicated by increase in the number of excavators owned from three to 40 in five years. The partnership was credited for its contributions in laying the foundation for some of the tallest buildings in Kuala Lumpur. The partnership garnered trust and received invitations for closed tenders; the partnership became a preferred, first-tier contractor in Kuala Lumpur.

The financial crisis in 1997 adversely affected the partnership and the construction industry in Malaysia. A trading partner, WL, who was a project manager at a public-listed infrastructure construction company, advised CC to focus on selective small-scale dismantlement work. Selective small-scale dismantlement work is frequently required prior to any major demolition work. Examples of selective small-scale dismantlement work include removal of connections between buildings prior to the demolition of any building. Such dismantlement work requires precise demolition skills, which are not easy to master and thus not many demolition service providers are in a position to offer such services. WL trusted CC's technical competence in performing selective small-scale dismantlement work. Further, such dismantlement work is typically paid on a cash basis. CC followed WL's advice and concentrated on such dismantlement work to tide over the financial crisis.

In light of WL's sound advice and vast experience as a project manager, CC invited WL to become a partner, which WL accepted. WL's role was to oversee the partnership's projects, which was similar to WL's previous role at the public-listed company, but the partnership's projects were of a smaller scale. With WL in the management team, the partnership continued to concentrate on honing its unique expertise in selective small-scale dismantlement work. At times when projects were scarce, the partnership did not lower its price due to the belief that 
the partnership offered above-average quality dismantlement work. The partnership expanded its business operations beyond the capital city while still concentrating on selective small-scale dismantlement work. In the early 2000 s, the partnership became a private limited company as per WL's advice in order to have access to more capital resources.

\section{The Company and its External Environment: Capturing Opportunities}

While the company was comfortable with its revenue, especially from selective small-scale dismantlement work, the company constantly looked for more sources of revenue. The company found that the by-product of demolition work, which is scrap metal, constituted a major source of revenue as well. The company invested in bucket lorry and other equipment to manage scrap metal. As price of scrap metal fluctuates, the company first attempted to maintain a consistent supply of scrap metal to obtain a better, more stable price. Next, the company diversified into scrap metal recycling, which was found to be more lucrative. Finally, the company arrived at an even better alternative, which was to keep scrap metal and only sell them when demand is high, particularly when there is a surge in demand from mainland China.

Having found a more lucrative alternative to manage scrap metal, the bucket lorry and employees involved in scrap metal recycling became redundant. The company decided to offer construction waste removal services to fully utilize excess human and machinery resources. Once the company began to offer construction waste removal services, the company was surprised by the high demand for such services as few in the market could offer similar services at the price level that the company offered. The company obtained a loan to expand its fleet of bucket lorry from one to five units, and buckets from three to 21 units to cope with the high demand for construction waste removal services. CC's two children participated in the management of the company to cope with the corresponding increase in management workload.

The global financial crisis in 2009 drove demolition service providers to look for avenues to minimize costs as the market became more price sensitive. CC invited his brother-in-law, YY, to participate in the management team. YY was a backhoe expert. With YY in the management team, the company was able to provide demolition services at a lower price using backhoe. The company also offered rock hacking services using backhoe for quarry plants. The company's trading partner, KU, a quarry plant manager, suggested that the company produces crushed stones for road building and cement mixing. CC followed KU's suggestion and used the company's connections with the construction and cement manufacturing companies to distribute crushed stones. CC received positive feedback on the quality of crushed stones supplied.

In 2009, a mishap resulting in the collapse of a building and seven casualties brought the previously unregulated demolition services sector to the authorities' attention, namely the Construction Industry Development Board (CIDB) and Department of Occupational Safety and Health (DOSH). CC claimed that approximately 90 percent of the company's demolition projects were suspended as a result of the authorities' intervention. Only minor demolition projects were allowed to proceed. Used machinery and equipment for demolition work became widely available for sale at a bargain in line with closure of several small demolition service providers. Major construction companies that used to outsource demolition work began to acquire used machinery and equipment to perform their own demolition work in-house. 
As demolition projects in the capital city were scarce, $\mathrm{CC}$ decided to venture into property investment in 2011 as the property market began to recover from the global financial crisis. CC invited TY, an experienced property developer and commercial land investor primarily in the southern region of peninsular Malaysia, to participate in the management team. The company invested in commercial and residential properties.

\section{Discussions}

In summary, the case firm constantly discovered avenues for improvement in response to changing environmental circumstances. First, the case firm concentrated on perfecting its skill in providing earthwork and demolition services, i.e. its principal activities. The case firm grew from a sole proprietorship to a partnership and eventually to a private limited company. In addition to earning trust in the construction industry and its position as a preferred, first-tier contractor in demolition services, the firm also demonstrated its unique expertise as a specialist in small-scale dismantlement work where few could master. Besides demonstrating depth in its contributions to the value chain as a specialist in small-scale dismantlement work, the case firm also offered a breath of products and services to the construction value chain; the case firm supplied scrap metal and crushed stones as well as offered construction waste removal services.

Before a business is in a position to contribute to the value chain, the entrepreneur and the business need to be self-sufficient first. Returning to the basics of entrepreneurship, "entrepreneurship is the ability to create and build something from practically nothing" (Timmons, 1989: p. 1). The owner-manager of the case firm focused on building or developing himself and his family first. Motivated by the desire to upgrade his family's socioeconomic status, the owner-manager of the case firm migrated to the city as a teenager ill-equipped with formal education let alone capital resources. In the city, the owner-manager managed to continuously equip himself with the relevant experience, expertise, capital and other necessary resources to start his own business. Even when his business was making good progress, the owner-manager did not rest on his laurels but continuously identified avenues for improvement to the extent that the business became self-sufficient as reflected in the depth and breadth of case firm's contributions to the construction value chain.

Such undaunted desire for self-sufficiency and progress led to the development of a range of entrepreneurial capabilities from adaptability, diligence and resilience to technical competence, which in turn earned the owner-manager trust and credibility. Having developed trust and credibility paved the way for development of business relationships that are commercially beneficial, such as the win-win liaison with the machinery supplier and access to overseas market - mainland China - as a scrap metal supplier. Further, trust and credibility also won sound advice and assistance at each juncture of the development of the case firm, from growth and expansion to specialization and diversification. Advice and assistance received reflects concerns about the well-being of the owner-manager and survival of his business, particularly in difficult times like the Asian Financial Crisis where the owner-manager was advised to focus on small-scale dismantlement work that pays in cash. Hence, business networks developed was not solely commercial but also social.

Despite having developed such crucial business networks that are commercially as well as socially beneficial, political ties with the authority were overlooked as indicated by suspension of several demolition projects after a mishap in 2009. History suggests that political ties with 
the authority enable indigenous entrepreneurs in Malaysia to enjoy various benefits ranging from special privileges, licenses, access to government funding and even monopoly conditions, resulting in a "quick rich mentality" and "dependency syndrome" among the indigenous community (Chin 2012; Chin \& Teh, 2017). Political ties with the authority have inadvertently created a shortcut towards financial rewards and success leaving indigenous entrepreneurs with little sense of urgency for personal development and self-sufficiency, which often involve toil and sweat. Political ties with the authority and the resultant financial rewards spare indigenous entrepreneurs from having to "create and build something from practically nothing" (Timmons, 1989: p. 1), which is the essence of entrepreneurship. However, having to establish political ties consume resources and may require giving up autonomy in decision-making and tolerating rent-seeking activities of the authority (Mai et al., 2015). The case firm channelled its resources primarily into developing a self-sufficient firm rather than establishing political ties. In other words, lack of political ties and thus shortcuts to financial rewards inadvertently left the case firm with no choice but to be self-sufficient.

\section{Concluding Remarks}

Motivated by the desire to understand how SMEs can play a more important role in global socio-economic development, this study provides a historical perspective of Chinese entrepreneurs in Malaysia and the journey of a long-standing Chinese SME. In summary, Chinese entrepreneurs portray the very essence of entrepreneurship, which enables them to thrive even when contextual circumstances are unfavourable. Chinese entrepreneurs have a strong desire for self-sufficiency and progress in life where they consistently upgrade themselves with experience, expertise, business networks and other relevant resources. The case firm demonstrates continuous improvement in efficiency and effectiveness where its contributions to the value chain grow endlessly both in depth and in breath. Indigenous entrepreneurs in Malaysia need to emulate their Chinese counterparts and toil their way towards self-sufficiency as the government is becoming overburdened with public expenditure where deregulation and economic liberalization will eventually be the only way forward (Chin \& Teh, 2017).

This study sheds light on the pertinent entrepreneurial capabilities for aspiring entrepreneurs to cultivate. Aspiring entrepreneurs need to view obstacles and hardship as stepping stones to cultivate and demonstrate their entrepreneurial capabilities just like how the founder of the case firm consistently found opportunities to enhance and/or diversify income streams when each source of income met with obstructions or was simply deemed inadequate. Being able to survive and even prosper in times of adversity also constitute testimony of resilience and reliability, which garner trust and loyalty. Being able to garner trust and loyalty is beneficial in many ways; world most successful entrepreneurs like Bill Gates and Warren Buffet have trusted and loyal business partners (see Eisner \& Cohen, 2012). As evidenced in the case firm, trusted trading partners can offer advice, form alliances and even participate in the management of the business to help the business tide over difficult times and prosper. At the very minimum, trusted business partners provide moral support, which boosts confidence and optimism in the face of challenges (Eisner \& Cohen, 2012).

As for policy makers, findings of this study suggest the need to exercise care in offering grants, loans and other forms of financial assistance to help financially challenged SMEs. Challenges and crises are not uncommon in business and in life in general. It is not challenges and crises that break a business but one's response towards challenges and crises (see Cawthorn, 2013). 
With little financial assistance and thus shortcut, SMEs are left with no choice but to toil and sweat their way towards financial solutions, which helps to build character in the process. In light of the importance of character-building, more emphasis on education, training and learning among entrepreneurs is required. Continuous support in the form of technical assistance, advisory services, mentorship and counselling to promote long-term learning is important particularly when cultivation of entrepreneurial capabilities is a life-long process (Timmons, 1989).

While this study sheds light on the key Chinese entrepreneurial capabilities and practices in Malaysia, results of this study have to be interpreted with caution as generalizability is not the intention of this study. Having to solicit participation in interpretive case studies is challenging particularly when a high degree of trust, commitment, and willingness to open up and disclose private information are required. As a consequence, this study managed to solicit participation of only one case firm. Future research can consider exploring how historical development in mainland China and other Southeast Asian countries shape entrepreneurial capabilities and practices to ascertain the generalizability of this study and for a better understanding of the variations, if any, in the pertinent entrepreneurial capabilities and practices that contribute towards business success across geographic regions.

\section{References}

Ahlstrom, D., Young, M. N., Chan, E. S. \& Bruton, G. D. (2004). Facing contraints to growth? Overseas Chinese entrepreneurs and traditional business practices in East Asia. Asia Pacific Journal of Management, 21, 263-285.

Ahmad N. H., Ramayah, T., Wilson, C. \& Kummerow, L. (2010). Is entrepreneurial competency and business success relationship contingent upon business environment? International Journal of Entrepreneurial Behaviour and Research, 16(3), 183-203.

Belassi, W. \& Tukel, O. I. (1996). A new framework for determining critical success/failure factors in projects, International Journal of Project Management, 14(3), 141-151.

Bird, B. (1995). Towards a theory of entrepreneurial competency, in Katz, J. A. And Brockhaus, R. H. (Eds), Advances in Entrepreneurship, Firm Emergence and Growth, Vol. 2, JAI Press, Greenwich, CT, 73-96.

Cawthorn, S. (2013). Bounce forward: How to transform crisis into success. John Wiley and Sons, Melbourne.

Chin, Y. W. (2012). The evolution of Malaysia's development strategies and the global economy: Responses from SMEs and civil societies. Copenhagen Journal of Asian Studies, 30(1), 11-35.

Chin, Y. W. \& Teh, B. C. G. (2017). Malaysia's protracted affirmative action policy and the evolving Bumiputra commercial and industrial community, Journal of Social Issues in Southeast Asia, 32 (2), 336-373.

Cook, S., Lu, J., Tugendhat, H. \& Alemu, D. (2016). Chinese migrants in Afrika: Facts and fictions from the agri-food sector in Ethiopia and Ghana. World Development, 81, 6170.

Constantino, F., Gravio, G. D. \& Nonino, F. (2015). Project selection in project portfolio management: An artificial neural network model based on critical success factors. International Journal of Project Management, 33, 1744-1754.

Dyer, W. G. Jr. \& Wilkins, A. L. (1991). Better stories, not better constructs, to generate better theory: A rejoiner to Eisenhardt. Academy of Management Review, 16(3), 613-619. 
Eisner, M. D. \& Cohen, A. R. (2012). Working together: Why great partnership succeeds. HarperCollins Publisher, New York.

Elinio, E. (2009). The effect of government subsidies on private R\&D: Evidence from geographic variation in support program funding. Helsinki Center of Economic Research (HECER) Discussion Paper No. 263.

Ghosh, B. N. \& Abdad, M. Z. (1998). The Chinese community and the growth of ethocentric capitalism in Malaysia. Humanomics, 14(2), 49-58.

Harvie, C. (2015). SMEs, trade and development in Southeast Asia. International Trade Centre (ITC) Working Paper Series WP-01-2015E. Available at http: www.intracen.org/publications

Ho, K. L. (2006). Competition, (ir)relevance and market determinants: Government economic policies and ethnic Chinese responses in Malaysia, in Suryadinata, L. (Ed.), Southeast Asia's Chinese Businesses in an Era of Globalization: Coping with the Rise of China, Singapore: Institute of Southeast Asian Studies, Singapore.

Huang, X. (2009). Strategic decision making in Chinese SMEs. Chinese Management Studies, 3(2), 87-101.

Khong, H. L. \& Jomo, K. S. (2010). Labour Market Segmentation in Malaysian Services, NUS Press, Singapore.

Lau, Y. W. (2013). Government-linked companies' (GLCs) performance - a structuration perspective: Malaysian evidence. International Journal of Critical Accounting, 5(2), 213-227.

Li, T. \& Gustafsson, V. (2012). Nascent entrepreneurs in China: Social class identity, prior experience affiliation and identification of innovative opportunity. Chinese Management Studies, Vol. 6 No. 1, pp. 14-35.

Li, Y., Su, Z., Liu, Y. \& Li, M. (2011). Fast adaptation, strategic flexibility and entrepreneurial roles. Chinese Management Studies, 5(3), 256-271.

Mai, Y., Xiong, C. \& He, X. (2015). The effects of entrepreneurs' socio-economic status and political characteristics on new ventures' establishment of formal political ties in China. Chinese Management Studies, 9(2), 130-149.

Matzler, K., Bailom, F. \& Mooradian, T. A. (2007). Intuitive decision making. MIT Sloan Management Review, 49(1), 13-15.

Mitchelmore, S. \& Rowley, J. (2010). Entrepreneurial competencies: a literature review and development agenda. International Journal of Entrepreneurial Behaviour and Research, 16(2), 92-111.

Myers, M. D. (2009). Qualitative research in business and management. London, UK: Sage.

Neck, H. M. \& Greene, P. G. (2011). Entrepreneurship education: Known worlds and new frontiers. Journal of Small Business Management, 49(1), 55-70.

Rahman, S. A., Amran, A., Ahmad, N. H. \& Taghizadeh, S. K. (2015). Supporting entrepreneurial business success at the base of pyramid through entrepreneurial competencies. Management Decision, 53(6), 1203-1223.

Rao, C.P., Ross-Larson, B. Noordin, S. \& Tjao, H.G. (1977). Issues in Contemporary Malaysia, Heinemann Educational Books (Asia) Ltd., Kuala Lumpur.

Reeves, M. \& Deimler, M. (2011). Adaptability: The new competitive advantage. Havard Business Review, July-August.

Saleh, A. S. \& Ndubisi, N. O. (2006). An evaluation of SME development in Malaysia. International Review of Business Research Papers, 2(1), 1-14. 
Sarwoko, E., Surachman, Armanu \& Hadiwidjojo, D. (2013). Entrepreneurial characteristics and competency as determinants of business performance in SMEs. Journal of Business Management, 7(3), pp. 31-38.

Saunders, B., Sim, J., Kingstone, T., Baker, S., Waterfield, J., Bartlam, B., Burroughs, H. \& Jinks, C. (2017). Saturation in qualitative research: Exploring its conceptualization and operationalization. Quality \& Quantity, DOI 10.1007/s11135-017-0574-8

Schlevogt, K-A. (2002). The Art of Chinese Management: Theory, Evidence and Applications. Oxford University Press, USA.

Song, L., Rogoff, E. G., Foo, C-T. \& Liu, X. (2015). The effect of entrepreneurial context on the performance of new ventures. Chinese Management Studies, 9(2), 197-220.

Timmons, J. A. (1989). The Entrepreneurial Mind. Brick House Publishing, Andover MA.

Wee, V., Jacobsen, M. \& Wong, T. C. (2006). Positioning strategies of Southeast Asian Chinese entrepreneurs. Journal of Contemporary Asia, 36(3), 364-384.

Welter, F. (2011). Contextualizing entrepreneurship-Conceptual challenges and ways forward. Entrepreneurship Theory and Practice, 35(1), 165-184.

Wonglimpiyarat, J. (2011). Government programmes in financing innovations: Comparative innovation system cases of Malaysia and Thailand. Technology in Society, 33, 156-164.

Yan, S. (2015). China has a bigger middle class than America, CNN Money, October 14. http://www.money.cnn.com

Zattoni, A., Gnan, L. \& Huse, M. (2015). Does family involvement influence firm performance? Exploring the mediating effects of board processes and tasks. Journal of Management, 41(4), 1214-1243. 